\title{
What future for the Department of Health?
}

\author{
Rudolf Klein
}

Almost from its birth the NHS has been haunted by a vision. In it, the service emerges from the tutelage of central government as an independent corporation emancipated from control by civil servants and no longer vulnerable to sudden ministerial whims or political pressures. It is an idea that has surfaced from time to time, as in the report of the 1979 Royal Commission'; it has also been considered in private ministerial ruminations about the future of the NHS. In the past it has usually been dismissed as tempting but politically naive and constitutionally irregular. Now, however, its time may have come. In 1992 the NHS Management Executive is to move to new headquarters in Leeds. The move will give even more visibility to its increasingly independent role and force into the open a debate that has already begun within the Department of Health: a debate about the respective roles of the executive and the department. If the management executive is the body responsible for running the NHS - a sort of protocorporation, albeit at present still embedded in central government - what is the department's future?

\section{Leadership for the NHS}

The origins of the management executive, as of so much else in the NHS today, go back to the 1983 Griffiths report, ${ }^{2}$ which recommended the creation of two new boards. The first, to be chaired by the secretary of state, was to be the Health Services Supervisory Board, responsible for determining the "purpose, objectives and direction" of policy. The second, to be chaired by an outsider with managerial skill, was to be the NHS Management Board, whose role it would be to implement policy, to give leadership to the management of the NHS, to control performance, and "to achieve consistency and drive over the long term." In his report Sir Roy Griffiths explicitly recognised that this was an alternative way of achieving many of the objectives sought by the advocates of an independent corporation but without calling into question the secretary of state's constitutional position or requiring time consuming legislation to implement the change. The appointment of a general manager for the NHS to act as the secretary of state's "right hand man" would leave undisturbed the secretary of state's "clear responsibility for overall policy direction and for the handling of the public and political sensitivities of the service."

It was a tactful formulation. But tensions were inevitable. According to the then permanent secretary, Sir Kenneth Stowe, "It was nearly a disaster." boards were duly set up in 1985. Mr Victor Paige, an experienced manager, was brought in to chair the management board, which was composed partly of career civil servants and partly of specialists, drawn mainly from the private sector but also from the NHS, with specific managerial skills in personnel, procurement, and property. By June 1986, however, Paige had resigned. The minister for health was brought in to chair the management board while Mr Len Peach, its director of personnel, became chief executive. The distinction between the supervisory and the management boards, a key element in Sir Roy's original architectural design, soon became blurred, with overlapping memberships - for example, the chief medical officer and the chief nursing officer sat on both boards.

\section{... There has been a successful rearguard action in defence of the civil service status quo.}

There was increasing doubt whether the supervisory board had any role at all, while the management board concentrated chiefly on implementing the Griffiths report - that is, on the task of creating a new managerial structure and style within the NHS. Up to 1989 and the publication of the NHS review, ${ }^{4}$ a turning point in the board's history, the management board was thus essentially an instrument for promoting managerial and technical efficiency. Its activities ranged from the introduction of new pay systems for managers ${ }^{5}$ to the resource management initiative ${ }^{6}$ and from promoting the better use of buildings and land 7 to exploiting the commercial possibilities of hospitals. ${ }^{8}$ The activities were carried out with missionary zeal-the outside members of the board, in contrast to civil servants, deliberately adopted a high public profile-but remained essentially technical.

Up to the publication of the 1989 review, a reasonable verdict on the management board might therefore have been that, though it had brought in a welcome infusion of technical skills and managerial drive, it had not quite lived up to the original specifications or expectations. In particular, it had not succeeded in establishing itself as the equivalent of an independent corporation, or anything approaching it, and remained embedded in the departmental structure. It is an outcome which can best be seen as the product of two sets of pressures. First, there were the political or ministerial pressures: the requirements of parliamentary accountability meant that it was difficult to insulate policy implementation from day to day political turbulence. Second, there were the civil service pressures: the existence of the board was potentially a threat to the existing departmental hierarchy.

The clearest statement of the effect of political inhibitions on the board's role was made by Victor Paige when explaining the reasons for his resignation to the House of Commons Social Services Committee. ${ }^{9}$ "The reality is that Ministers take all the important decisions, political, strategic and managerial," he wrote in his memorandum, "Because of that, the intention to devolve executive accountability and authority from the Secretary of State effectively did not happen... The Management Board and its Chairman did not 'manage' in the way that would be understood 
in industry and commerce." Indeed, it is clear that the permanent secretary, Sir Kenneth Stowe, thought that it was naive to believe otherwise and that the expectations that the board might mark the beginning of emancipation from ministerial interference were completely unrealistic. "The main source of the unrealisable expectation," he wrote, "was our old friend, the grand illusion that somehow a mechanism could be and had been devised under which Government would hand over £15b plus per annum of Exchequer Funds to be spent at discretion by independent authorities with Ministers and their officials kept at arm's length." While ministers had to answer questions in parliament about everything that happened in the NHS regular ministerial interventions in management were inevitable. Furthermore, ministers were not prepared to put themselves at arm's length from regional and district chairmen: a political line of accountability ran in parallel with the managerial one.

However, the creation of the management boardseen as exercising an independent management function - was not only incompatible with the doctrine of parliamentary accountability but also threatening to Sir Kenneth Stowe and his civil servant colleagues. The civil servants at the department had for long been preoccupied with the problems of bringing together the various streams of policymaking within the Elephant and Castle and had made a succession of changes within the hierarchy in an attempt to create a more coherent sense of direction. To this extent, the creation of the board might have been welcome to them. But it also introduced competition for the ears of ministers; the chairman (later chief executive) of the board was an accounting officer in his own right, able to answer directly to parliamentary committees. More crucially still, as the report of the social services committee on the Griffiths report commented, "Amidst the general furore over the proposed identification of general managers, the fact that the report quietly proposed the decimation of what used to be the Ministry of Health has gone almost unnoticed." the social services committee pointed out, the Griffiths report explicitly recommended that "the DHSS should rigorously prune many of its existing activities" and that "a small general management body . . . is almost all that is necessary at the centre for the management of the NHS." At the time, there were between 2500 and 3000 staff (depending on definitions) dealing with health matters at the DHSS. The figure now is much the same. So, clearly, there has been a sucessful rearguard action in defence of the civil service status quo.

\section{A second coming}

New impetus for change came, however, with the publication of the 1989 review. This reiterated, but with added emphasis and explicitness, the philosophy of the Griffiths report. Though recognising that ministers would continue to be accountable to parliament for "policy and strategy," it emphasised that they should not be "involved in operational decisions." A new policy board, including outsiders, would be responsible for strategy, while the NHS Management Executive would "deal with all operational matters within the strategy and objectives" set by the board. The secretary of state would chair the policy board; the chief executive would chair the management executive (and would, moreover, be consulted about its membership). The overall effect, the review claimed, would be to "introduce for the first time [my italics] a clear and effective chain of command running from Districts through Regions to the Chief Executive and from there to the Secretary of State." Lastly, primary health care was incorporated into the structure.
The membership of the board, ${ }^{11}$ in particular, seemed to ratify the shift of power in the health policy arena symbolised by the way in which the review had been produced. The policy board consists of the secretary of state and his ministerial colleagues, $\mathrm{Sir}$ Roy Griffiths, the permanent secretary, the NHS chief executive, two regional chairmen, and three industrialists. There are also two medical members - the chief medical officer and Professor Cyril Chantler-both of whom, however, serve in their personal capacity. There is, therefore, no ex officio medical voice. The membership of the executive, however, did not seem to mark any major change. The chief executive, $\mathrm{Mr}$ Duncan Nichol a former regional manager, had previously served on the management board. The other members are three civil servants, two outside experts (on finance and estates management), a director of nursing, and a medical director drawn from the department's own ranks. The executive represents, as yet, not a new administrative machinery but a new way of orchestrating the existing corps of civil servants and a new channel of influence leading directly to the secretary of state. It is an embryo within the body of the department, whose capacity to live an independent existence has yet to be tested.

But the review also gave the management executive a new mission, with the result that it has achieved a higher profile than its predecessor. It is the executive that is responsible for implementing the various policy innovations, ranging from the creation of hospital trusts to practice budgets. It is the executive that set the timetable and that is the driving force behind the changes: a reminder that it was invented in part at least because of the feeling that, though traditional civil servants might be highly skilled in putting policy options before ministers, they were not equipped for managing and implementing change. There has been a subtle shift of style, with the chief executive taking a more assertive, positive public stance: witness his leading role during the ambulance dispute. The function of the management executive is increasingly presented as being not merely to execute policies decided by others but to shape the future NHS. Introducing the management executive's goals to the NHS hierarchy earlier this year, Duncan Nichol wrote: "What I have sought to establish is that the Management Executive is more than simply the management 'delivery' arm of the NHS. As you are, so are we in the business of health, concerned to identify and tackle the major health care challenges facing the NHS." 12 There has been a shift from implementing managerial policies to implementing health policies, from a preoccupation with structure to a concern with content.

Most important of all, perhaps, the management executive is sustained by changes in the Whitehall environment. In 1988 the Prime Minister's efficiency unit published a revolutionary manifesto. Entitled The Next Steps, ${ }^{13}$ it recommended "fundamental changes" in the Whitehall machinery: "The aim should be to establish a quite different way of conducting the business of government." The function of central government departments should be limited, as far as possible, to devising the framework of policy and monitoring performance. The executive functions of government should be transferred to agencies with maximum freedom to determine how centrally determined objectives should be met: "The presumption must be that, provided management is operating within the strategic direction set by Ministers, it must be left as free as possible to manage within that framework." In effect, the philosophy of the 1983 Griffiths report was to be generalised to the whole of government. The Department of Social Security has already divested itself of managerial responsibility for 
the running of its local offices, setting up a new agency to carry out this task. And the NHS Management Executive, from being a somewhat one off experiment, has become the flagship of what may turn out to be a revolution in government. Not the least reason for its success in asserting its identity so strongly is that the Prime Minister expects a regular report on its progress: it enjoys the protection of Number 10 and is seen as something of a test case.

In some respects, then, the future of the Department of Health and of the NHS Management Executive depends on the political environment. In part it will reflect the influence of the political actors involved. At present, the Prime Minister, secretary of state, and chief executive are all concerned to promote the role of the management executive: an alliance that diminishes the ability of senior civil servants to influence events, whatever their private misgivings. If there was any change of actors, there might also be a change of course. In part, however, the future of the department and the executive will depend on whether, independent of the personalities concerned, there will continue to be a trend towards restricting the role and size of Whitehall and extending that of agencies. Although The Next Steps manifesto is very much associated with the Thatcher regime - and derives its force from the Prime Minister's strong personal support-many of its arguments echo those of the 1968 Fulton committee set up by a Labour prime minister. It was this committee that argued for "hiving off" activities, including those in social fields, to autonomous public boards. It would therefore be a mistake to assume that any change of political direction would necessarily reverse the trend set by The Next Steps. The revolution in the "business of government" is less the child of political ideology than the product of information technology, which allows activity at the periphery to be monitored by the centre without any hands on interference.

\section{NHS: Who will call the shots?}

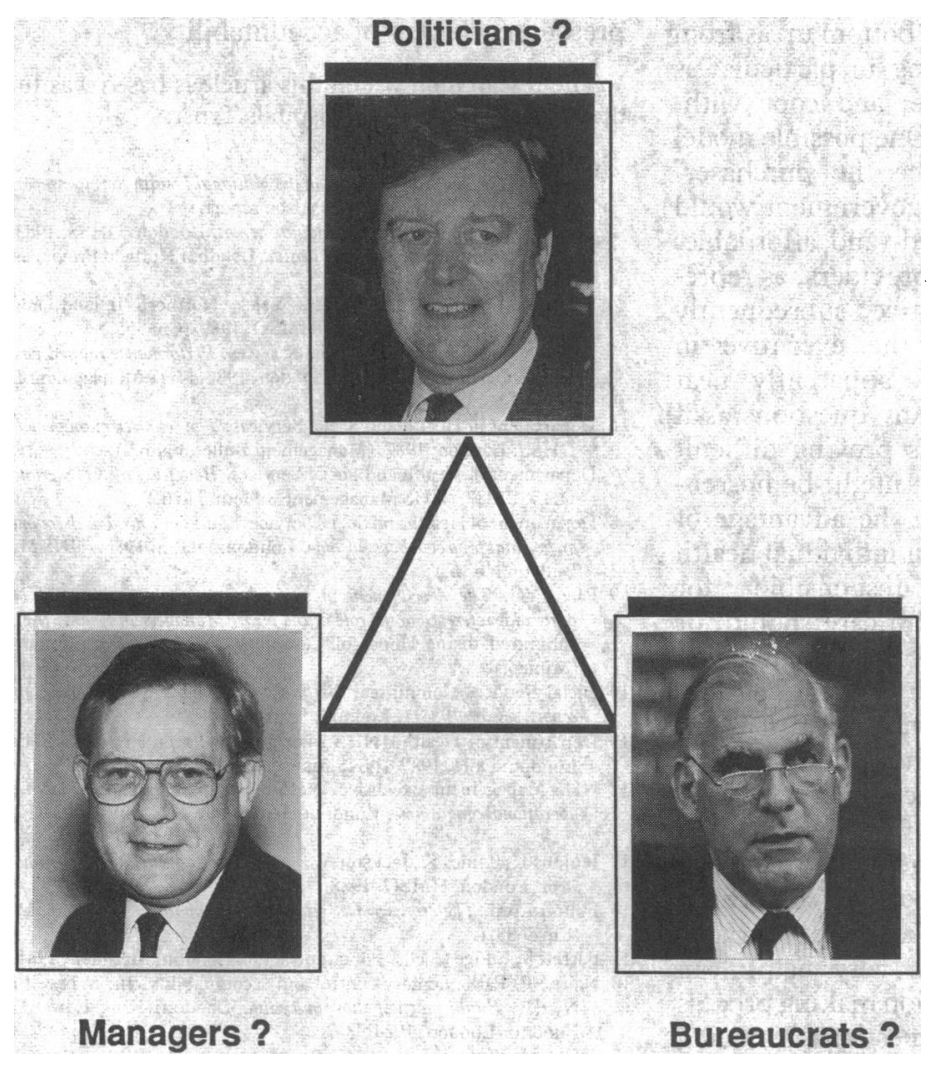

Looking ahead to 1992 , it is possible to see at least two possible lines of development. The first is the minimal change scenario, under which the NHS Management Executive would become a kind of semidetached outpost of the Department of Health: where there would be geographical decentralisation without, necessarily, any change in the balance of power. The second is the maximum change scenario, under which the NHS Management Executive would rapidly move towards the status of an independent agency, leaving a much shrunk Department of Health with radically altered functions. There may well be halfway houses between these approaches, as well as considerable pressures to blur the choices at least in the short run, but concentrating on these alternatives helps to identify and sharpen up the issues involved: issues that affect everyone working in the NHS as they will affect the way in which the service operates and develops.

\section{Semidetached outpost or independent agency?}

The minimal change scenario implies a commuting civil service. At present the integration of the functions of the Department of Health and of the management executive depends, very largely, on the fact that it is the same civil servants who are answerable to both the permanent secretary and to the chief executive. There is therefore surprisingly little evidence of any clash of loyalties or conflict of interest: the management of policy and the management of the NHS is, by and large, in the same hands. If this is to be sustained, however, when the management executive moves then clearly civil servants will have to move regularly between London and Leeds with spells of duty in each place. If they do not there may develop a de facto division between the department and the executive, with the executive seeing itself as the champion of the NHS in opposition to central government (with all the risk this carries, in the eyes of the Treasury, of an authoritative voice publicly demanding extra funds). Achieving such a regular two way movement of people, however, may be difficult: how, for example, will ambitious civil service high flyers be reassured that Leeds is not a place of exile, where reputations made in Whitehall die a long, slow death through oblivion? In short, although the minimal change scenario may be attractive in that it seems to entail no fundamental change in the relation between the department and the executive, it may be difficult to manage and could turn out to be only a temporary expedient if the Leeds outpost were to develop its own sense of corporate identity.

In any case, even a minimal change scenario would require decisions about who goes where-that is, the division of the existing corps of civil servants. At present it is largely possible to fudge this issue, given that everyone is in London. Moreover, the complex and contentious legislation that followed the 1989 review gave prominence to one of the traditional civil service roles, which is precisely to prepare for legislation and to assist ministers in getting bills through parliament. Now that it is possible to contemplate (perhaps overoptimistically) a longish period without green or white papers, new regulations or contracts, let alone major bills, it is also possible to contemplate radically shrinking the number of civil servants. As the Fulton committee pointed out, the appropriate model might be that of Sweden: "In Sweden central departments deal in the main with policy-making: they are quite small and are predominantly staffed by younger men." But if this model were to be followed this would imply a departmental staff counted in hundreds where it is now counted in thousands - concentrating perhaps on the management of the Whitehall environment (and 
particularly the Treasury) instead of the management of the NHS.

Splitting staff also means - indeed follows - splitting responsibilities. It would mean deciding who does what. For example, who would be responsible for pay negotiations - the department or the executive? To ask this question is to underline that the neat distinction between policy and management, so often used to distinguish the roles of the department and of the executive, may easily break down in practice. On the one hand, pay deals clearly have policy or strategic implications for both the rest of the public sector and the economy as a whole. This is why, of course, salary settlements concerning the medical profession and other professions may often become Cabinet matters; there seems therefore to be a strong case for keeping this as a departmental matter. Conversely, however, it is difficult to see how any management can control its organisation if the biggest variable determining its financial performance is outside its control. So there seems to be an equally strong case for making this an executive matter. And the case for so doing will inevitably grow stronger if there is a continuing trend towards decentralising pay bargaining and a consequential shift from dealing with national organisations like the BMA to negotiating with local groups, whether in hospital trusts or elsewhere. So even if the executive's move were not intended to be the start of a new era, even if it meant only that there was also to be a Department of Health in exile in Leeds, there would still have to be a resolution of issues that affect everyone working in the NHS. The need for such a resolution would, of course, be much more urgent still if the intention were to move towards the independent agency solution: the maximum change scenario. Not only would this reinforce the arguments for a dramatic reduction in the size of the department but it would also call for a precise definition of the respective roles of the department and the executive.

The main difficulty in drawing such a boundary has already been mentioned - that the conventional distinction between policy and management and between taking decisions about the direction in which the NHS should travel and implementing them is too facile. Policy gets made as much from the bottom up as from the top down. ${ }^{15}$ NHS policymaking in particular is often about how to accommodate, and cope with, clinical innovation and initiatives. One possible model for the future might therefore be the purchaserprovider relation. That is, central government would decide what health care is required (and affordable) and contract accordingly with the providers, as represented by the management executive, subsequently monitoring the performance of the executive in delivering the goods. Even this apparently neat solution, however, provokes as many questions as it answers. Writing local contracts is proving difficult enough; writing a national contract might be horrendously so (although it would have the advantage of forcing the government, rather than individual health authorities or clinicians, to accept responsibility for decisions about what kinds of health care should, or should not, be provided and for whom). Equally, who in the Department of Health should write the contract and monitor the executive's performance? If it is the civil servants, can they do so without getting some firsthand knowledge of what is happening in the NHS? And if they attempt to do so, will they not be duplicating the role of the management executive? Alternatively, should it be the new policy board? But if so, is the membership of the policy board appropriate? Bringing in industrialists may be very helpful in concentrating attention on the decision making process - on making sure that the right questions are being asked-but it is difficult to see what they have to contribute to shaping priorities for health, as distinct from managerial, policy-for example, the relative priorities that should be accorded to different client groups or forms of treatment. How, then, will medical and other professional advice be taken into account?

At least one other critical issue would have to be resolved if the management executive were to move towards independent agency status. As already noted, the main objection to such a move has always been the doctrine of parliamentary accountability. The secretary of state, it has been argued, cannot divest himself from day to day responsibility for what happens in the NHS as he is responsible to members of parliament for the expenditure of public monies. Hence Bevan's quip that "when a bed-pan is dropped on a hospital floor, its noise should resound in the Palace of Westminster" hence the weekly procession of parliamentary questioners; hence, finally, the much resented interventions by the secretary of state in even the most minor matters. In principle, there is no great difficulty in finding an appropriate formula. The secretary of state would be answerable for strategic policy; the chief executive (who already appears before parliamentary committees) would answer for the way in which services are delivered. Whether such a solution would be politically acceptable in the case of the NHS is, of course, a very different matter: the suspicion that professional paternalism is being replaced by managerial paternalism may create strong opposition.

Given all these highly contentious issues, it may well be that the NHS Management Executive's move to Leeds will represent a halfway house solution: that there will be no dramatic or explicit change of status but rather a slow slide into a different relationship with the Department of Health. Even so, it is clear that there are issues which require public debate. If the role of the Department of Health is to change then this has implications which go well beyond Whitehall. It will mean that professional negotiating routines forged over the past 40 years or so have to be rethought; it should prompt questions about the link between policy and professional advice; it must provoke argument about how best to ensure the sensitivity of the NHS to the needs of the population and how to improve on the present machinery of accountability.

The research on which this article is based was funded by the Nuffield Provincial Hospitals Trust.

Merrison, A. Royal commission on the National Health Service: report. London HMSO 1979. (Cm 7615.) (Merrison report.)

Griffiths R. NHS management inquiry: report. London: DHSS, 1983.

3 Stowe. On caring for the national health. London: Nuffield Provincial Hospitals Trust, 1989.

4 Secretaries of State for Health, Wales, Northern Ireland, and Scotland Working for patients. London: HMSO, 1989. (Cm 555.)

5 Department of Health and Social Services. Performance related pay introduced for general managers. DHSS: London, 1986. NHS Management Bulletin No 2.)

6 Department of Health and Social Services. The resource management initiative. DHSS: London, 1987. (Management Bulletin No 7 .)

7 Department of Health and Social Services. Better use of NHS estate. London DHSS, 1987. (NHS Management Bulletin No 6.

8 Department of Health and Social Services. Talks go ahead with commercial sector on hospital project to boost income. London: DHSS, 1988. (NHS Management Bulletin No 16.

9 Paige VG. The development of general management within the NHS, with particular reference to the role of the NHS Management Board. Memorandum submitted to the House of Commons Social Services Committee. 1986, (Mimeo.)

10 Social Services Committee. Griffiths NHS management inquiry report. First report, session 1983-4. London: HMSO, 1984.

11 Department of Health. [NHS Management Executive; NHS Policy Board.] London: DoH, 1989. (NHS Management Bulletin No 21.)

12 NHS Management Executive. NHS management executive goals and 1990/91 operational programme. London: Department of Health, 1990. (EL (90) MB 77$.

13 Jenkins $\mathrm{K}$, Caines $\mathrm{K}$, Jackson A. Improving management in government: the next steps. London: HMSO, 1988.

14 Fulton Lord. The civil service: report of the committee. London: HMSO, 1968 (Cm 3638.)

15 Barrett S, Fudge C, eds. Policy and action London: Methuen, 1981

16 Nairne P. Parliamentary control and accountability. In: Maxwell R, Weaver N, eds. Public participation in health. London: King Edward's Hospital Fund for London, 1984:33-51.

(Accepted l August 1990) 